Oxygen and nitrogen impurities in microcrystalline silicon deposited under optimized conditions: Influence on material properties and solar cell performance

T. Kilper, W. Beyer, G. Bräuer, T. Bronger, R. Carius, M. N. van den Donker, D. Hrunski, A. Lambertz, T. Merdzhanova, A. Mück, B. Rech, W. Reetz, R. Schmitz, U. Zastrow, and A. Gordijn

Citation: Journal of Applied Physics 105, 074509 (2009);

View online: https://doi.org/10.1063/1.3104781

View Table of Contents: http://aip.scitation.org/toc/jap/105/7

Published by the American Institute of Physics

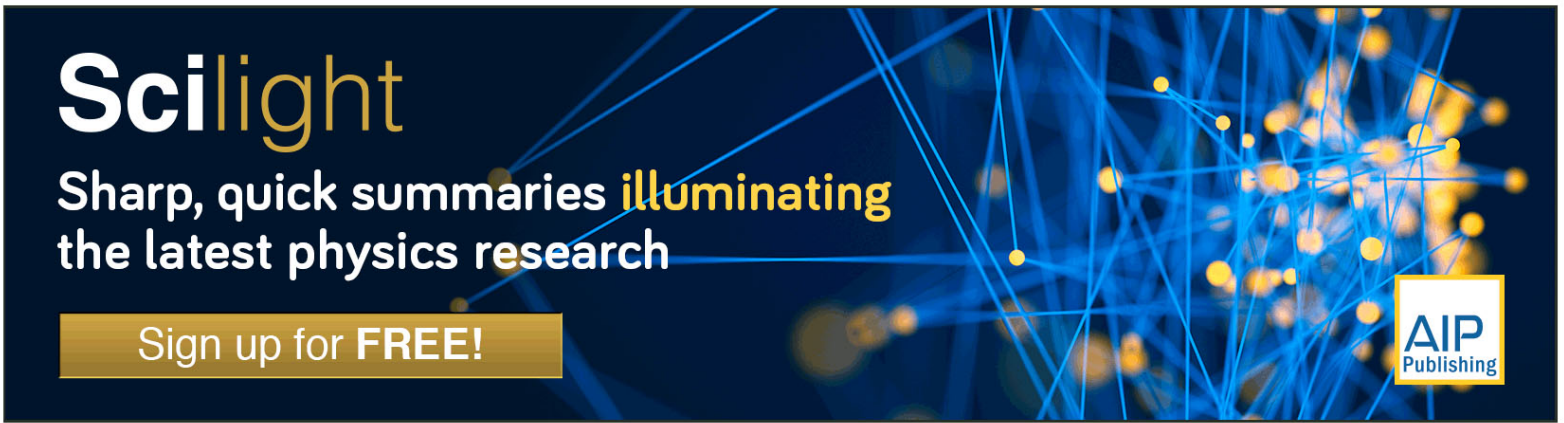




\title{
Oxygen and nitrogen impurities in microcrystalline silicon deposited under optimized conditions: Influence on material properties and solar cell performance
}

\author{
T. Kilper, ${ }^{1, a)}$ W. Beyer, ${ }^{1}$ G. Bräuer ${ }^{2, b)}$ T. Bronger, ${ }^{1}$ R. Carius, ${ }^{1}$ M. N. van den Donker, ${ }^{1, c)}$ \\ D. Hrunski, ${ }^{1}$ A. Lambertz, ${ }^{1}$ T. Merdzhanova, ${ }^{1}$ A. Mück, ${ }^{1}$ B. Rech, ${ }^{1,3, d)}$ W. Reetz, ${ }^{1}$ \\ R. Schmitz, ${ }^{1}$ U. Zastrow, ${ }^{1}$ and A. Gordijn ${ }^{1, e)}$ \\ ${ }^{1}$ IEF5-Photovoltaik, Forschungszentrum Jülich, D-52425 Jülich, Germany \\ ${ }^{2}$ Fraunhofer-Institut für Schicht-und Oberflächentechnik (IST), D-38108 Braunschweig, Germany \\ ${ }^{3}$ Abteilung SE1 (Silizium Photovoltaik), Hahn-Meitner-Institut Berlin, D-12489 Berlin, Germany
}

(Received 10 June 2008; accepted 21 February 2009; published online 8 April 2009)

\begin{abstract}
The influence of oxygen and nitrogen impurities on the performance of thin-film solar cells based on microcrystalline silicon $(\mu c-\mathrm{Si}: \mathrm{H})$ has been systematically investigated. Single $\mu c-\mathrm{Si}: \mathrm{H}$ layers and complete $\mu c-\mathrm{Si}: \mathrm{H}$ solar cells have been prepared with intentional contamination by admitting oxygen and/or nitrogen during the deposition process. The conversion efficiency of $\sim 1.2 \mu \mathrm{m}$ thick $\mu c-\mathrm{Si}: \mathrm{H}$ solar cells is deteriorated if the oxygen content in absorber layers exceeds the range from $1.2 \times 10^{19}$ to $2 \times 10^{19} \mathrm{~cm}^{-3}$; in the case of nitrogen contamination the critical impurity level is lower $\left([\mathrm{N}]_{\text {critical }}=6 \times 10^{18}-8 \times 10^{18} \mathrm{~cm}^{-3}\right)$. It was revealed that both oxygen and nitrogen impurities thereby modify structural and electrical properties of $\mu c-\mathrm{Si}: \mathrm{H}$ films. It was observed that the both contaminant types act as donors. Efficiency losses due to oxygen or nitrogen impurities are attributed to fill factor decreases and to a reduced external quantum efficiency at wavelengths of $>500 \mathrm{~nm}$. In the case of an air leak during the $\mu c-\mathrm{Si}: \mathrm{H}$ deposition process, the cell performance drops at an air leak fraction from 140 to $200 \mathrm{ppm}$ compared to the total gas flow during $i$-layer deposition. It is demonstrated that oxygen and nitrogen impurities close to the $p / i$-interface have a stronger effect on the cell performance compared to impurities close to the $n / i$-interface. Moreover, thick $\mu c-\mathrm{Si}: \mathrm{H}$ solar cells are found to be more impurity-sensitive than thinner cells. (C) 2009 American Institute of Physics. [DOI: 10.1063/1.3104781]
\end{abstract}

\section{INTRODUCTION}

Microcrystalline silicon ( $\mu c-\mathrm{Si}: \mathrm{H})$ emerged as a promising absorber material for photovoltaics. It combines the advantages of amorphous silicon $(a-\mathrm{Si}: \mathrm{H})$ and its thin-film technology with the stability and long wavelength spectral sensitivity of crystalline silicon. Solar modules consisting of $a$-Si:H top cells and $\mu c-\mathrm{Si}: \mathrm{H}$ bottom cells have yielded stabilized efficiencies above $10 \%$ on laboratory level. For single junction $\mu c$-Si:H solar modules efficiencies above $8 \%$ have been demonstrated. ${ }^{1,2}$

One prerequisite for the fabrication of high-efficiency $\mu c-\mathrm{Si}: \mathrm{H}$ solar cells is a low contamination level of impurities in the intrinsic $\mu c-\mathrm{Si}: \mathrm{H}$ absorber layer. ${ }^{3}$ There are several possible mechanisms resulting in an unintentional incorporation of foreign atoms during $\mu c-\mathrm{Si}: \mathrm{H} i$-layer deposition. Oxygen, nitrogen, and carbon contaminations may be introduced by impurities in the process gases hydrogen and silane

a) Tel.: +49 246161 1554. FAX: +49 246161 3735. Electronic mail: t.kilper@fz-juelich.de.

b) Tel.: +49 5312155 500. FAX: +49 5312155 900. Electronic mail: braeuer@ist.fhg.de.

${ }^{c}$ Present address: Solland Solar B.V., Bohr 10, NL-6422RL Heerlen, The Netherlands. Tel.: +31 458800 686. FAX: +31 458800 605. Electronic mail: mvandendonker@sollandsolar.com.

${ }^{\mathrm{d})}$ Tel.: +49 308062 1331. FAX: +49 308062 1333. Electronic mail: bernd.rech@hmi.de.

e) Author to whom correspondence should be addressed. Electronic mail: a.gordijn@fz-juelich.de. itself. Other sources for impurities are air leaks and/or outgassing in the deposition chamber indicated by an increased base pressure and in situ plasma cleaning procedures with $\mathrm{SF}_{6} / \mathrm{O}_{2}$ or $\mathrm{NF}_{3}$ before $\mu c-\mathrm{Si}: \mathrm{H}$ deposition. ${ }^{4,5}$

The present work addresses the influence of oxygen and nitrogen impurities on the properties of $\mu c-\mathrm{Si}: \mathrm{H}$ absorber layers and the performance of $\mu c-\mathrm{Si}: \mathrm{H}$ solar cells. Whereas previous studies were restricted to impacts on the $\mu c-\mathrm{Si}: \mathrm{H}$ material properties and to the influence of process gas purification on the spectral response of $\mu c-\mathrm{Si}: \mathrm{H}$ solar cells, we present a direct relation between oxygen and nitrogen content, the material properties, $I$ - $V$-parameters of solar cells, and external quantum efficiency (QE) measurements.

The previous studies performed by several research groups revealed that both the presence of oxygen and nitrogen influences the electrical and structural properties of microcrystalline silicon. For the incorporation of oxygen in $\mu c-\mathrm{Si}: \mathrm{H}$ films it was shown that it causes an increase in dark conductivity $^{3,6-8}$ and charge carrier density. ${ }^{8}$ Oxygen and nitrogen impurities in microcrystalline silicon were found to lead to donor states. ${ }^{9,10}$ Moreover, Electron Spin Resonance (ESR) studies have shown that oxygen contaminants lead to an increase in the spin density in microcrystalline silicon. ${ }^{10-12}$ It is found that the degree of hydrogen passivation has an important influence on the defect density. ${ }^{13}$ Therefore, low substrate temperatures during $\mu c-\mathrm{Si}: \mathrm{H}$ deposition are beneficial. ${ }^{14}$ It is speculated that oxygen atoms in 
microcrystalline silicon are located at the amorphous tissues and at the grain boundaries. ${ }^{8}$ Oxygen and nitrogen impurities are also found to affect the structural properties of microcrystalline silicon. The $\mu c-\mathrm{Si}: \mathrm{H}$ deposition regime is shifted toward a more amorphous growth both for oxygen ${ }^{8}$ and nitrogen impurities. ${ }^{9}$

This paper describes the quantification of critical oxygen and nitrogen impurity levels for the fabrication of highefficiency $\mu c-\mathrm{Si}: \mathrm{H}$ solar cells by correlating the oxygen and nitrogen $i$-layer content with the corresponding solar cell $I-V$-parameters. In parallel, changes in electrical and structural properties of $\mu c-\mathrm{Si}: \mathrm{H}$ absorber layers have been investigated. Moreover, we study the relationship between air leak flow and cell performance and the relation between cell thickness and impurity sensitivity. Also the role of local distribution of oxygen and nitrogen impurities within the $\mu c-\mathrm{Si}: \mathrm{H}$ absorber layer has been examined. The same group also investigates the influence of atmospheric contaminants on the properties of amorphous silicon. ${ }^{15}$

\section{EXPERIMENTAL DETAILS}

Applying a state-of-the-art $13.56 \mathrm{MHz} \mu c-\mathrm{Si}$ :H PlasmaEnhanced Chemical Vapor Deposition (PECVD) process, all solar cells were fabricated in a parallel plate capacitively coupled plasma reactor. It consisted of two electrodes, $150 \mathrm{~cm}^{2}$ in area and $1.0 \mathrm{~cm}$ apart, between which a plasma was ignited by applying a $13.56 \mathrm{MHz}$ rf signal onto the lower electrode. The substrates $\left(10 \times 10 \mathrm{~cm}^{2}\right)$ were mounted to the upper electrode. The glasses plates were coated by in-house magnetron sputtering with $\mathrm{ZnO}: \mathrm{Al}$ that was textured subsequently by wet chemical etching. ${ }^{16,17}$ In order to reduce unintentional oxygen and nitrogen impurities, the $\mathrm{SiH}_{4}$ and $\mathrm{H}_{2}$ feed gases were conducted through a gas purifier (SAES PS11-PG1-Si) before supplying homogenously to the plasma through showerhead holes in the lower electrode. For all $i$-layer depositions the hydrogen flow was kept constant at 360 SCCM (SCCM denotes standard cubic centimeter per minute at STP). All $\mu c-\mathrm{Si}: \mathrm{H}$ solar cells were prepared in $p-i-n$ sequence with a cell area of $1 \mathrm{~cm}^{2}$. Depending on the applied silane flow rate $i$-layer deposition rate was between $0.26 \mathrm{~nm} / \mathrm{s}(1.7 \mathrm{SCCM})$ and $0.52 \mathrm{~nm} / \mathrm{s}(3.5$ SCCM) at a substrate temperature around $200{ }^{\circ} \mathrm{C}$. The back contact was Ag prepared by evaporation. Single $\mu c-\mathrm{Si}: \mathrm{H}$ layers for measuring material properties were deposited on undoped seed layers deposited under the same conditions as the $p$-layers in the solar cells. Corning Eagle 2000 glass and crystalline silicon $(c-\mathrm{Si})$ served as substrates.

For the preparation of intentionally contaminated $\mu c$-Si:H layers, a controllable leak was installed at the reactor wall of the $i$-chamber. The controllable leak served either as air leak or was connected with an oxygen $\left(\mathrm{O}_{2} 4.8\right.$ purity) or nitrogen $\left(\mathrm{N}_{2} 5.0\right.$ purity) gas cylinder. By opening up the controllable leak, the base pressure of the $i$-chamber was varied by three orders of magnitude between $10^{-8}$ and $10^{-5}$ Torr. For in situ diagnostics an Oriel MS257 spectrometer was used monitoring the optical emission of the plasma with the aim to identify spectral lines of oxygen and nitrogen.
The $I$ - $V$-curves of $\mu c$-Si: $\mathrm{H}$ solar cells under illumination (AM 1.5 spectrum, $100 \mathrm{~mW} / \mathrm{cm}^{2}, 25^{\circ} \mathrm{C}$ ) were measured using a continuous light $(\mathrm{dc})$ sun simulator of class A (Wacom). For determining the external $\mathrm{QE}$ of $\mu c-\mathrm{Si}: \mathrm{H}$ solar cells, monochromatic probe beams with wavelengths from 300 to $1100 \mathrm{~nm}$ were used, and the differential spectral responses at 0 and $-0.5 \mathrm{~V}$ bias voltage were measured. Secondary ion mass spectrometry (SIMS) depth profiles were performed to determine the concentration of oxygen, carbon, and nitrogen in the $\mu c-\mathrm{Si}: \mathrm{H}$ layer using a quadruple instrument (Atomika 4000). The residual gas pressure in the SIMS analysis chamber was $<10^{-10}$ Torr. Primary $\mathrm{Cs}^{+}$ions at near-normal incidence with energies of $6 \mathrm{keV}$ were used and negative secondary ions were detected. Employing a sputtering rate of $>0.5 \mathrm{~nm} / \mathrm{s}$, we obtain in float zone $c$-Si the oxygen and nitrogen detection limits of $<5 \times 10^{17}$ and $<7$ $\times 10^{16} \mathrm{~cm}^{-3}$, respectively. ${ }^{18}$

Raman spectroscopy was performed both on single $\mu c$-Si:H layers and on $\mu c-\mathrm{Si}: \mathrm{H}$ solar cells of which the amorphous $n$-layers were removed by $\mathrm{KOH}$ etching. For excitation with $647 \mathrm{~nm}$ laser light the estimated probing depth is about $1 \mu \mathrm{m}$. The ratio $I_{C}{ }^{\mathrm{RS}}$ of the crystalline contributions near 520 and $500 \mathrm{~cm}^{-1}$ to the total integrated intensity of the Raman scattered TO signal was used as measure for the crystalline volume fraction of the film. ${ }^{19,20}$ Infrared (IR) absorption measurements were conducted using a Fourier transform spectrometer system Nicolet 5700 in order to investigate the different $\mathrm{Si}-\mathrm{H}$ and $\mathrm{Si}-\mathrm{O}$ bonds in $\mu c-\mathrm{Si}: \mathrm{H}$ layers that were deposited on $c$-Si substrates. IR transmission was measured in the range of $400-4000 \mathrm{~cm}^{-1}$.

The measurements of dark and photoconductivities were conducted in a coplanar two-point configuration using evaporated Ag contacts. To avoid the atmospheric influence, the measurements (at room temperature) were performed in high vacuum after annealing the samples for $30 \mathrm{~min}$ at $160{ }^{\circ} \mathrm{C}$. The photoconductivity measurements were done using a tungsten lamp, calibrated with a reference sample against the intensity of the solar simulator (AM 1.5 spectrum, $100 \mathrm{~mW} / \mathrm{cm}^{2}$ ). Details of the Hall measurements are described in detail in Ref. 21. Hall samples were structured and contacted photolithographically in order to minimize offset voltages. The typical Hall geometry was $6 \times 1.9 \mathrm{~mm}^{2}$, having two pairs of Hall contacts. The Hall setup used in the experiments holds the sample in a dark, evacuated cryostat, with a magnetic flux of $1.9 \mathrm{~T}$ through the samples, while the base voltage can be set between 10 and $1000 \mathrm{~V}$. The measurement of intrinsic $\mu c-\mathrm{Si}: \mathrm{H}$ films is difficult due to of high sample resistances.

All SIMS depth profiles, Hall measurements, conductivity measurements, IR absorption measurements, and Ramanscattering measurements were performed immediately after taking the $\mu c-\mathrm{Si}: \mathrm{H}$ samples out of the deposition chamber. Thereby an appreciable impact on the measurement results by the atmospheric indiffusion of $\mathrm{H}_{2} \mathrm{O}, \mathrm{O}_{2}$, or $\mathrm{N}_{2}$ is reduced as much as possible. 


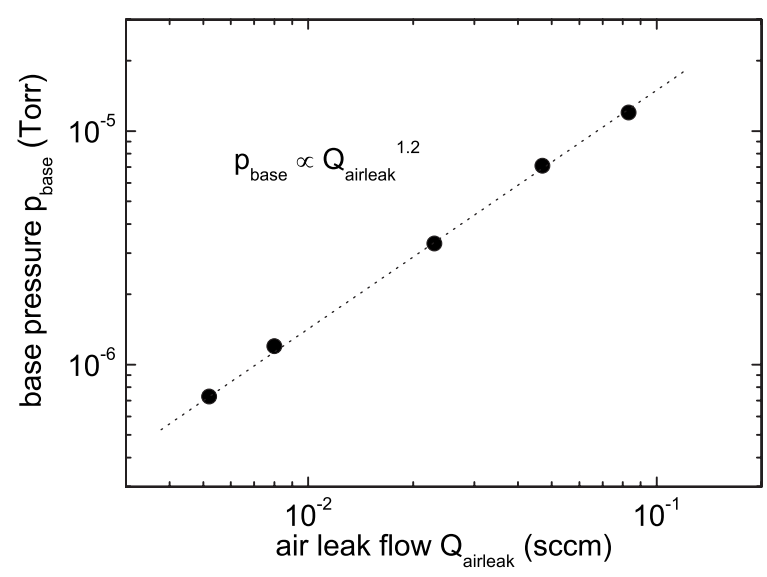

FIG. 1. Base pressure $p_{\text {base }}$ vs air leak flow $Q_{\text {airleak }}$ for various air leak rate settings. The dotted line serves as guide to the eyes.

\section{RESULTS}

\section{A. Correlation between air leak flow and $\mu c-\mathrm{Si}: \mathrm{H}$ solar cell performance}

With the aid of a needle valve, air was admitted to the reactor in small quantities. In this way $\mu c-\mathrm{Si}: \mathrm{H}$ absorber layers were intentionally contaminated with both oxygen and nitrogen. The base pressure in the reactor could be varied by changing the air leak size. The leak flow (in SCCM) is considered as a reactor-independent quantity to define an occurring leak in a deposition chamber. For various air leak rates, the actual air leak flow was estimated by monitoring the pressure increase versus time with closed pumping valves. The correlation with the corresponding base pressures (measured with open pumping valves) is shown in Fig. 1. It is observed that base pressure $p_{\text {base }}$ rises with air leak flow $Q_{\text {airleak }}$ according to $Q_{\text {airleak }} \propto p^{1.2}$.

To address the question which air leak flow values deteriorate the cell performance due to the incorporation of oxygen and nitrogen, we prepared a series of $\sim 1.2 \mu \mathrm{m}$ thick $\mu c-\mathrm{Si}: \mathrm{H}$ solar cells with air leak and various base pressures. The absorber layer of each solar cell was deposited in the desired regime close to the transition to amorphous growth since highest $\mu c-\mathrm{Si}: \mathrm{H}$ solar cell efficiencies are found in this regime. The crystalline volume fraction is controlled by adjusting the silane concentration $\mathrm{SC}=\left[\mathrm{SiH}_{4}\right] /\left(\left[\mathrm{SiH}_{4}\right]+\left[\mathrm{H}_{2}\right]\right)$ of the source gas mixture. The open-circuit voltages of solar cells deposited under efficiency optimized silane concentration (referred to as "optimum phase mixture") are typically $520 \mathrm{mV}$, whereas for higher silane concentrations they increase up to typically $800 \mathrm{mV}$ corresponding to amorphous $i$-layer materials. ${ }^{22,23}$ For obtaining the optimum phase mixture for all contamination levels in this experiment, silane flows between 3.0 and 3.5 SCCM (at a fixed hydrogen flow of $360 \mathrm{SCCM}$ ) were needed. When using the same silane flow for the whole series, the open-circuit voltages of the cells with higher impurity levels increase considerably, indicating that the material is too amorphous. Therefore, for the higher impurity levels, decreased silane flows were applied in order to keep the open-circuit voltage values as constant as possible.

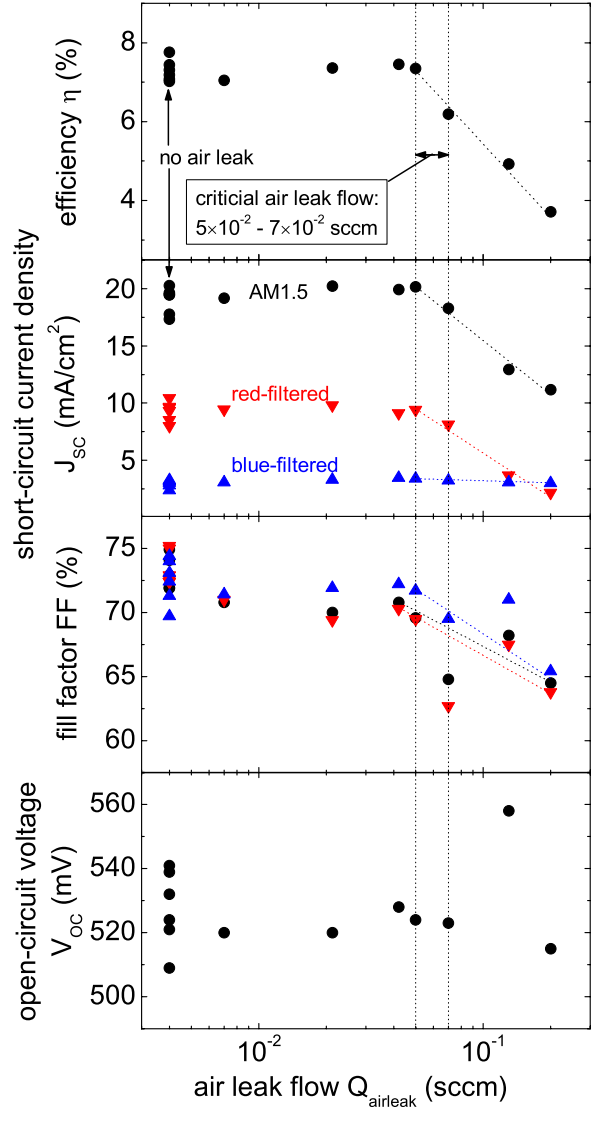

FIG. 2. (Color online) $I-V$-parameters of $\sim 1.2 \mu \mathrm{m}$ thick $\mu c-\mathrm{Si}: \mathrm{H}$ solar cells as a function of the leak flow $Q_{\text {airleak. }}$. Short-circuit current densities and fill factors are denoted under white (AM1.5), red (OG590 filter), and blue (BG7 filter) light illumination. The dotted lines serve as guides to the eyes.

In Fig. 2 the $I-V$-values of this series are plotted versus the corresponding air leak flows. It is seen that a constant efficiency is found up to a critical air flow in the range from $5 \times 10^{-2}$ to $7 \times 10^{-2} \mathrm{SCCM}$. At higher air flows, the cell efficiency starts to drop. This drop is mainly due to a decrease in the short-circuit current density in the red spectral range. The used silane flows at the threshold were 3.0 SCCM. The results imply that the $\mu c-\mathrm{Si}: \mathrm{H}$ solar cell performance is affected if the air leak flow fraction in relation to the total gas flow exceeds the range from 140 to $200 \mathrm{ppm}$. SIMS depth profiles revealed that the first $\mu c$-Si:H solar cell in this series with a lowered efficiency of $6.2 \%$ (prepared at an air leak flow of $7 \times 10^{-2} \mathrm{SCCM}$ ) contained $7 \times 10^{18}$ oxygen and $4 \times 10^{19} \mathrm{~cm}^{-3}$ nitrogen.

\section{B. Influence of $\mu c$-Si: $\mathrm{H}$-layer thickness}

To study the influence of oxygen and nitrogen impurities on $\mu c-\mathrm{Si}: \mathrm{H}$ solar cell with different $i$-layer thickness, we prepared a series of $\mu c-\mathrm{Si}: \mathrm{H}$ solar cells with a variation in $i$-layer thickness from 400 to $3000 \mathrm{~nm}$. The $\mu c-\mathrm{Si}: \mathrm{H}$ absorber layers were prepared with air leaks at corresponding base pressures of $10^{-6}$ and $10^{-5}$ Torr, respectively, and a reference series of $\mu c-\mathrm{Si}: \mathrm{H}$ solar cells without air leak has been made. Analyzing short-circuit current density values in Fig. 3 at low and high impurity levels (base pressures of $10^{-6}$ and $10^{-5}$ Torr, respectively), it can be concluded that thin 


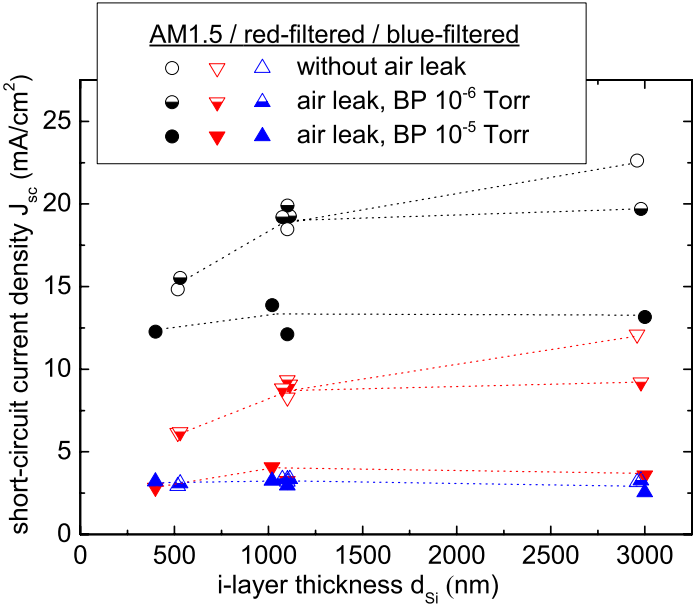

FIG. 3. (Color online) Short-circuit current density of $\mu c-\mathrm{Si}: \mathrm{H}$ solar cells for white (AM1.5), red (OG590 filter), and blue (BG7 filter) light illumination at different $i$-layer thicknesses and atmospheric impurity contents. The dotted lines serve as guides to the eyes.

$\mu c$-Si:H solar cells $\left(d_{\mathrm{Si}} \leq 1 \mu \mathrm{m}\right)$ are significantly less sensitive to oxygen and nitrogen impurities than thick cells $\left(d_{\mathrm{Si}} \sim 3 \mu \mathrm{m}\right)$. Furthermore it is observed that the decrease in short-circuit current density of the thicker cells is mainly due to a decrease in the red response (the spectral range between 600 and $1000 \mathrm{~nm}$ ).

\section{Role of local distribution of oxygen and nitrogen impurities}

The influence of oxygen and nitrogen impurities on the solar cell performance in dependence of their local depth distribution within the $\mu c-\mathrm{Si}: \mathrm{H}$ absorber layer was investigated. Hereto, we prepared a $\sim 1.2 \mu \mathrm{m} \mu c-\mathrm{Si}: \mathrm{H}$ solar cell of which the absorber layers were alternately grown with three different oxygen and nitrogen impurity levels. During the first $400 \mathrm{~nm}$ of $i$-layer deposition, a large air leak corresponding to a base pressure of $3 \times 10^{-5}$ Torr was applied, which results in high oxygen and nitrogen impurity levels compared to an uncontaminated reference cell as one can see in Fig. 4(a) (SIMS depth of $\sim 800-1200 \mathrm{~nm}$ ). Then the middle part of the $i$-layer was deposited with a base pressure of $10^{-6}$ Torr. Figure 4(a) shows the corresponding lower oxygen and nitrogen impurity levels for this middle part ranging from $\sim 400$ to $\sim 800 \mathrm{~nm}$. The preparation of the last $i$-layer part finally was performed without air leak. A further decrease in the nitrogen impurity level can be distinguished at a SIMS depth from $\sim 80$ to $\sim 400 \mathrm{~nm}$. The $I-V$-characteristics (not shown) of the $\mu c-\mathrm{Si}: \mathrm{H}$ solar cell with the SIMS depth profile as shown in Fig. 4(a) were similar to those with absorber layers of continuously high oxygen and nitrogen contamination; efficiency was $3.7 \%$, fill factor was $61.3 \%$, and short-circuit current density was $11.2 \mathrm{~mA} / \mathrm{cm}^{2}$ at an open-circuit voltage of $532 \mathrm{mV}$.

A second $\mu c$-Si:H solar cell with an $i$-layer sandwich structure was prepared with the sequence of air leak sizes inverted. Figure 4(b) shows the corresponding SIMS depth profiles. The $I-V$-characteristics of that $\mu c-\mathrm{Si}: \mathrm{H}$ solar were not affected by this impurity distribution; efficiency was
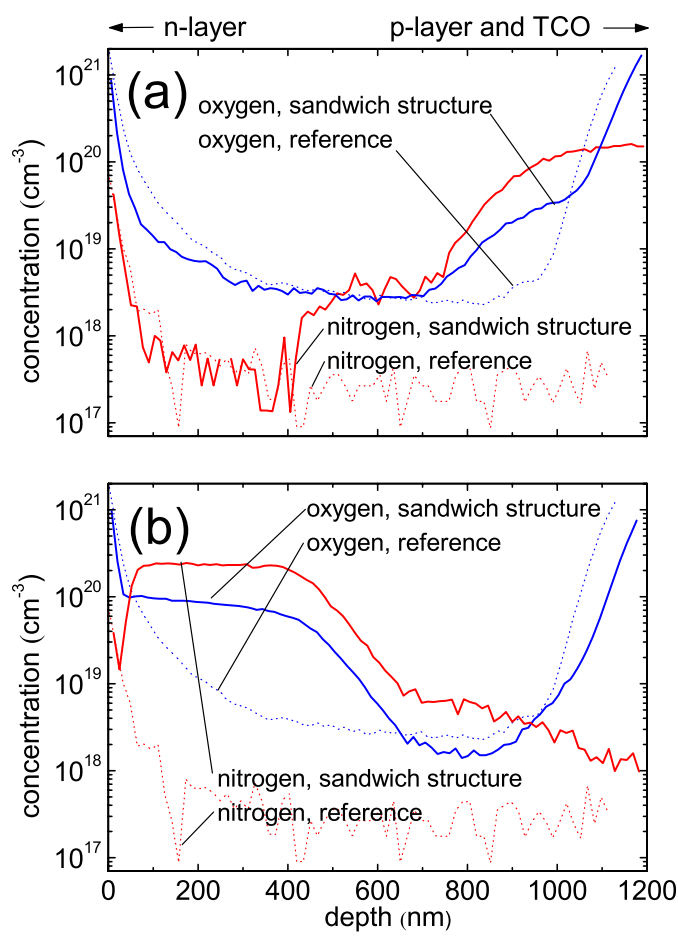

FIG. 4. (Color online) Oxygen and nitrogen SIMS depth profiles of $\mu c$-Si:H solar cells with $i$-layer sandwich structures alternately grown with three different air leak sizes. Compared to (a), the sequence of applied air leak sizes in (b) was exactly inverted. As reference also the oxygen and nitrogen SIMS depth profiles of a solar cell deposited without leak are shown.

$7.4 \%$, fill factor was $72.4 \%$, and short-circuit current density was $19.1 \mathrm{~mA} / \mathrm{cm}^{2}$ at an open-circuit voltage of $530 \mathrm{mV}$.

\section{Influence of oxygen impurities on the solar cell performance}

A series of $\sim 1.2 \mu \mathrm{m}$ thick $\mu c-\mathrm{Si}: \mathrm{H}$ solar cells with various oxygen gas flows was prepared. For an $i$-layer deposition in a regime close to the transition to amorphous growth, we gradually reduce the silane concentration at increasing oxygen gas flow in order to keep the $V_{\text {oc }}$ in the range of $520 \mathrm{mV}$ typical for transition-type $\mu c-\mathrm{Si}: \mathrm{H}$. Figure 5(a) shows the correlation between adjusted base pressure and measured $i$-layer oxygen concentration. For $\mu c-\mathrm{Si}: \mathrm{H}$ $i$-layer depositions without oxygen leak, the base pressure in the $i$-chamber was approximately $3 \times 10^{-8}$ Torr, and the measured oxygen concentration in the deposited $\mu c-\mathrm{Si}: \mathrm{H}$ layers was between $2 \times 10^{18}$ and $4 \times 10^{18} \mathrm{~cm}^{-3}$. The deposition with the smallest oxygen leak size was performed at an oxygen leak rate that corresponds to a base pressure of 3.8 $\times 10^{-7}$ Torr. For this leak size, no change in oxygen concentration could be detected. However, for larger oxygen leaks the oxygen concentration is systematically increasing as a function of the base pressure. The Nitrogen concentration of these films was found to remain small $\left([\mathrm{N}] \leq 10^{18} \mathrm{~cm}^{-3}\right)$.

Figure 6(a) shows the $I$ - $V$-parameters measured for $\mu c-\mathrm{Si}: \mathrm{H}$ solar cells as a function of the oxygen concentration in the $i$-layer. In this case, the cells with high impurity content were deposited with reduced silane concentrations in order to obtain roughly equal open-circuit voltage values. Whereas $\mu c$-Si:H solar cells with low oxygen content were 

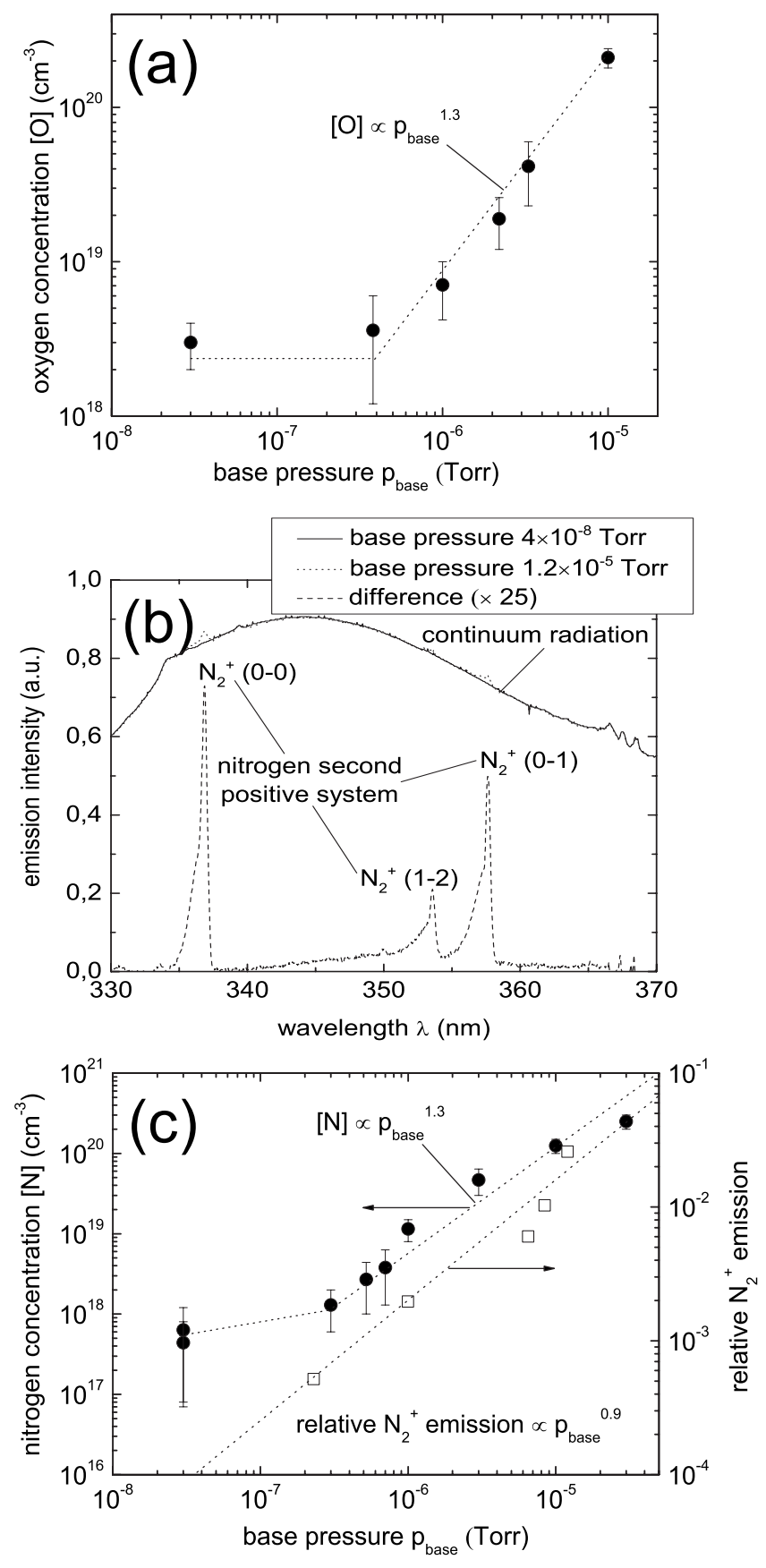

FIG. 5. Oxygen concentration [O] of $\mu c-\mathrm{Si}: \mathrm{H}$ absorber layers vs base pressure $p_{\text {base }}$ of the $i$-chamber varied by a controllable oxygen leak (a). The dotted line serves as guide to the eyes. Optical emission spectrum for a deposition without nitrogen leak corresponding to a base pressure of 4 $\times 10^{-8}$ Torr and for a deposition with nitrogen leak corresponding to a base pressure of $1.2 \times 10^{-5}$ Torr (b). The difference between the two spectra is plotted on a different scale. Nitrogen concentration $[\mathrm{N}]$ of $\mu c-\mathrm{Si}: \mathrm{H}$ absorber layers and relative $\mathrm{N}_{2}^{+}$emission during $i$-layer deposition vs the base pressure $p_{\text {base }}$ of the $i$-chamber for various nitrogen leak rate settings (c). The dotted line serves as guide to the eyes.

prepared at a silane flow of $3.3 \mathrm{SCCM}$, the $\mu c-\mathrm{Si}: \mathrm{H}$ solar cell with the highest oxygen content of $1.9 \times 10^{21} \mathrm{~cm}^{-3}$ was deposited at a silane flow of 1.7 SCCM. Solar cells prepared under these high oxygen flows at a silane flow of 3.3 SCCM had open-circuit voltages of roughly $800 \mathrm{mV}$ (instead of around $520 \mathrm{mV}$ ), indicating that $i$-layer material became amorphous. The figure shows that for oxygen concentrations of up to the range from $1.2 \times 10^{19}$ to $2 \times 10^{19} \mathrm{~cm}^{-3}$, the solar cell efficiency is not affected by impurities. Above this impurity level solar cell efficiency starts to drop continuously due to a reduced short-circuit current density and fill factor. Figure 6(a) shows that also fill factor and short-circuit current density measured under red light illumination decrease strongly with increasing oxygen concentration, while under blue light illumination they stay constant also for high impurity levels.

External QE spectra of $\mu c$-Si:H solar cells with different oxygen content are shown in Fig. 7(a). The sample with an oxygen concentration of $4.2 \times 10^{19} \mathrm{~cm}^{-3}$ exhibits significant QE losses at wavelengths of $>500 \mathrm{~nm}$ compared to the reference $\mu c-\mathrm{Si}: \mathrm{H}$ solar cell. The $\mathrm{QE}$ of the sample with the highest oxygen content in this series ([O]=1.9 $\left.\times 10^{21} \mathrm{~cm}^{-3}\right)$ is further decreased for the whole wavelength range. The strongest differences compared to the uncontaminated reference cell occur in the longer wavelength range from 500 to $900 \mathrm{~nm}$. Furthermore it can be seen that under negative bias voltage conditions, the external $\mathrm{QE}$ of the poor cells is enhanced. This indicates that oxygen contamination leads to a charge collection problem in the cells.

\section{E. Correlation between oxygen content and structural and electrical properties of $\mu c-\mathrm{Si}: \mathrm{H}$ films}

Figure 7(a) shows a strong decrease in the external QE at long wavelengths for solar cells with high oxygen content. High QEs also at long wavelengths are a typical feature of $\mu c-\mathrm{Si}: \mathrm{H}$ solar cells compared to $a-\mathrm{Si}: \mathrm{H}$ solar cells. Therefore, it needs to be determined whether this decrease coincides with a decrease in crystalline volume fraction. As mentioned before, throughout this series, the silane flow was adapted in order to compensate for the decrease in crystalline due to the oxygen incorporation. Raman spectra of $\mu c-\mathrm{Si}: \mathrm{H}$ solar cells with different oxygen content were taken [Fig. $8(\mathrm{a})]$. It can been seen that the $\mu c-\mathrm{Si}: \mathrm{H}$ solar cells with high oxygen content have a slightly higher crystalline volume fractions compared to solar cells with low oxygen content. This means that the decrease in crystallinity with increasing oxygen concentration was slightly overcompensated by decreasing the silane flow during the deposition process and the decrease in the QE is not caused by a reduced crystalline volume fraction. It is also noticeable that the band at $520 \mathrm{~cm}^{-1}$ related to the crystalline phase of the sample with the highest oxygen concentration is shifted to lower wave numbers. This phenomenon can be attributed to a higher degree of stress in the material ${ }^{24}$ or to a smaller grain size. ${ }^{25}$

To obtain additional information on the influence of oxygen on the structural and electrical properties, $\mu c-\mathrm{Si}: \mathrm{H}$ layers with different oxygen concentrations and a thickness of 1.1-1.5 $\mu \mathrm{m}$ were deposited on Corning glass and on $c$-Si substrates. The films were deposited under the same conditions as at the preparation of absorber layers of the $\mu c-\mathrm{Si}: \mathrm{H}$ solar cells, i.e., with adapted silane flows, in order to prevent the decrease in crystallinity upon oxygen contamination. From Raman measurements it can be deduced that the crystalline volume fractions of absorber layers in $\mu c-\mathrm{Si}: \mathrm{H}$ solar 

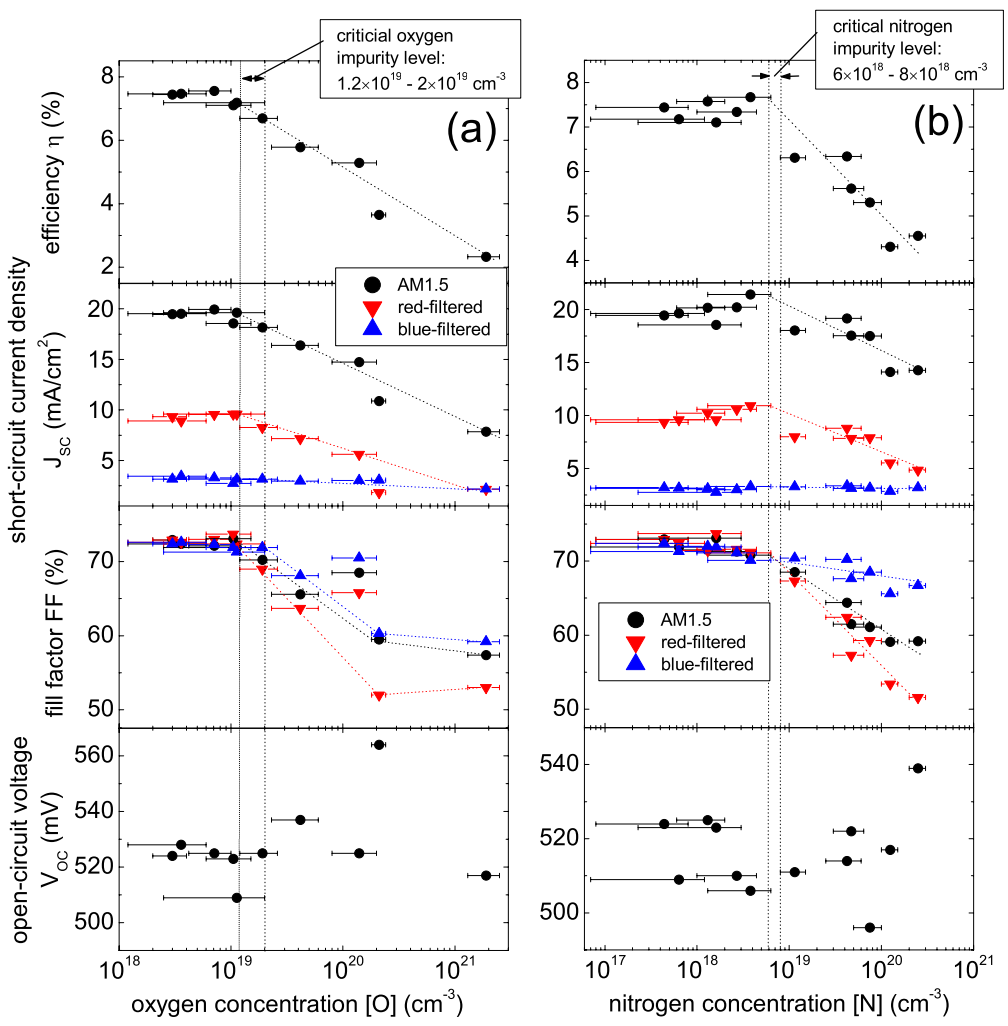

FIG. 6. (Color online) $I$ - $V$-parameters of $\sim 1.2 \mu \mathrm{m}$ thick $\mu c-\mathrm{Si}: \mathrm{H}$ solar cells as a function of the oxygen (a) and nitrogen (b) concentration in the absorber layer. Short-circuit current densities and fill factors are denoted for white (AM1.5), red (OG590 filter), and blue (BG7 filter) light illumination. The dotted lines serve as guides to the eyes.
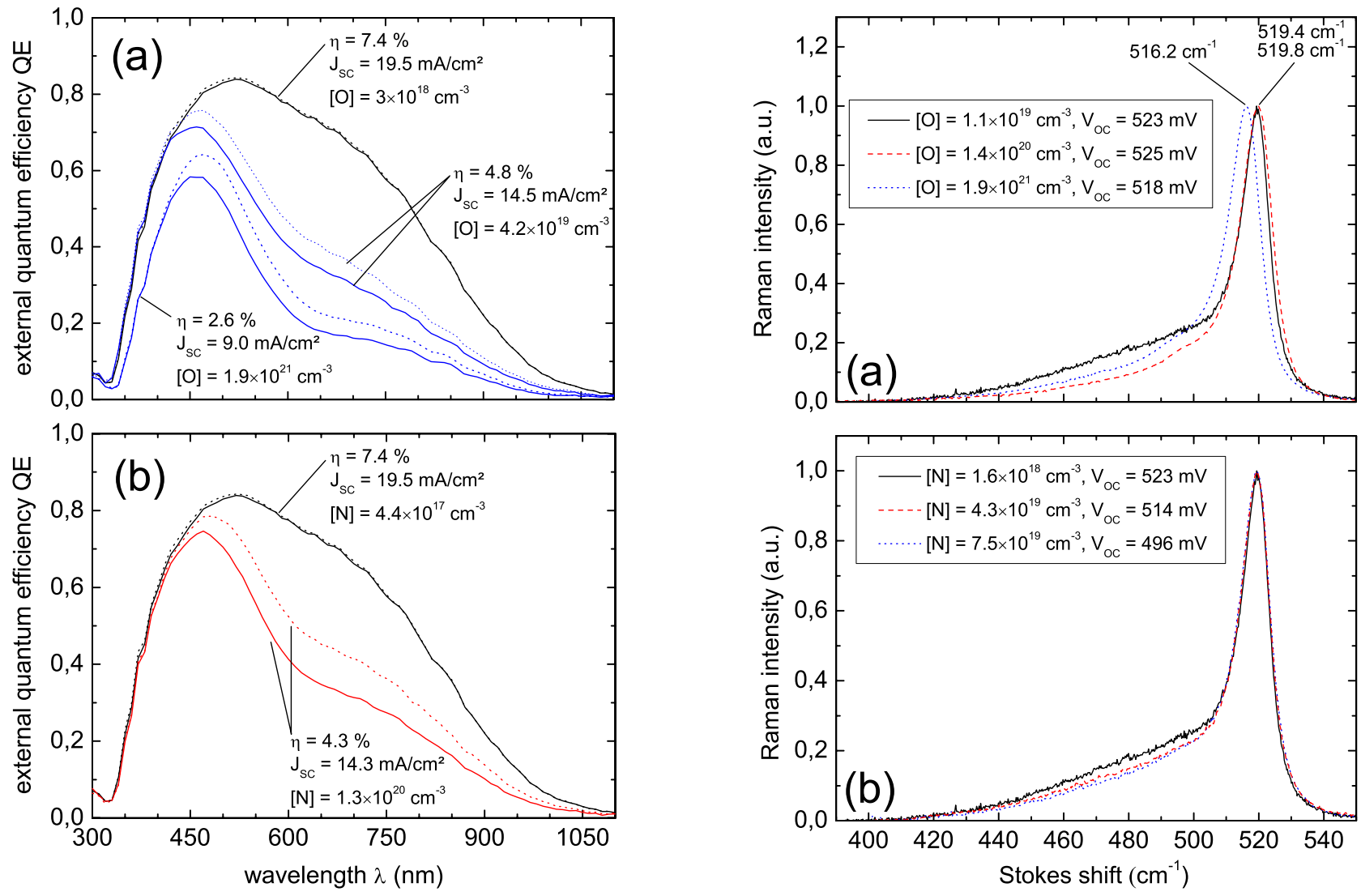

FIG. 7. (Color online) External QEs at $0 \mathrm{~V}$ (solid lines) and $-0.5 \mathrm{~V}$ (dotted lines) bias voltages of $\mu c-\mathrm{Si}: \mathrm{H}$ solar cells with various oxygen (a) and nitrogen (b) contents.

FIG. 8. (Color online) Raman spectra of $\sim 1.2 \mu \mathrm{m}$ thick $\mu c$-Si:H solar cells with absorber layers with various oxygen (a) and nitrogen (b) concentrations. 

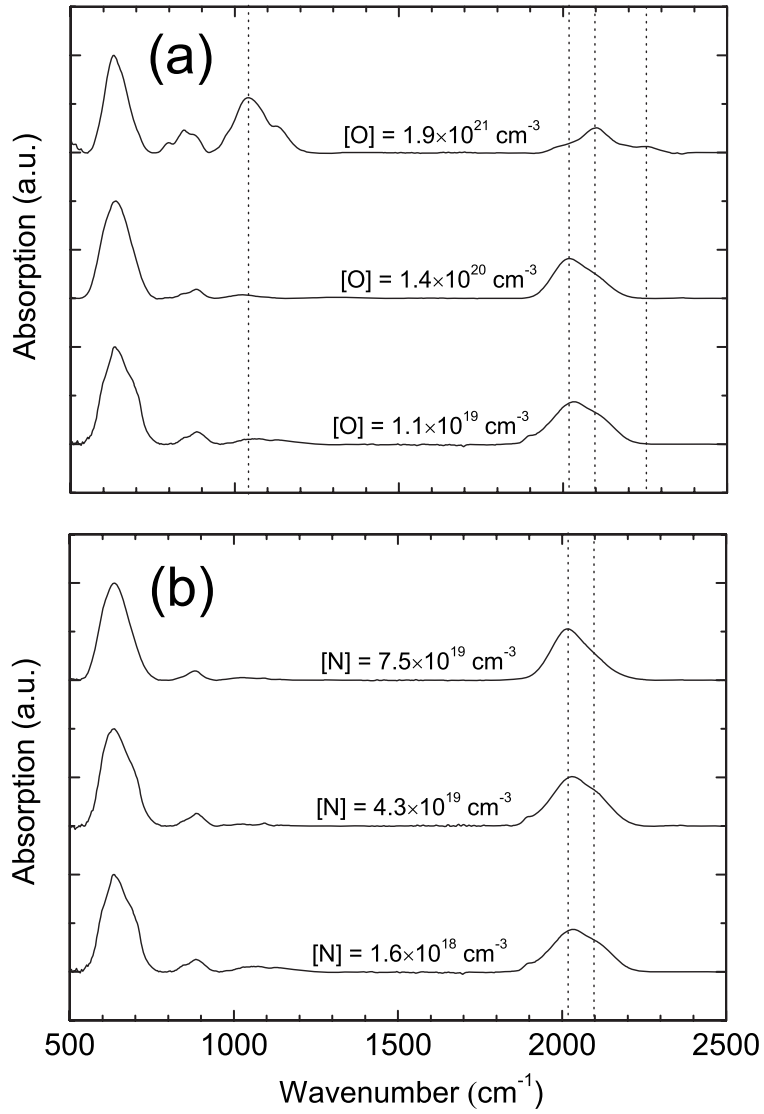

FIG. 9. IR absorption spectra of $\mu c-\mathrm{Si}: \mathrm{H}$ films with different oxygen (a) and nitrogen (b) concentrations. The individual spectra are shifted for clarity.

cells and of the corresponding $\mu c-\mathrm{Si}: \mathrm{H}$ films on Corning glass with equal oxygen content are very similar (not shown).

Figure 9(a) shows IR absorption spectra of the $\mu c-\mathrm{Si}: \mathrm{H}$ films deposited on $c$-Si substrates. The $\mu c-\mathrm{Si}: \mathrm{H}$ film with the highest oxygen content of $1.9 \times 10^{21} \mathrm{~cm}^{-3}$ has additional absorption around $1050 \mathrm{~cm}^{-1}$ attributed to $\mathrm{Si}-\mathrm{O}$ bonds. Also the $\mathrm{Si}-\mathrm{H}$ stretching mode at 2000 and $2100 \mathrm{~cm}^{-1}$ is affected by the oxygen impurities. Figure 9(a) shows that for the samples with oxygen concentrations of $1.1 \times 10^{19}$ and 1.4 $\times 10^{20} \mathrm{~cm}^{-3}$, the absorption peak at $\sim 2000 \mathrm{~cm}^{-1}$ is dominating, which indicates that the material is compact. On the other hand, the $\mu c-\mathrm{Si}: \mathrm{H}$ film with a higher oxygen concentration of $1.9 \times 10^{21} \mathrm{~cm}^{-3}$ shows a major contribution of the $2100 \mathrm{~cm}^{-1}$ absorption peak and an additional contribution around $2200 \mathrm{~cm}^{-1}$.

Hall and conductivity measurements have been performed to study electrical properties as a function of oxygen incorporation. The first result was that all samples are $n$-type, i.e., electrons are the majority carriers. Figure 10(a) shows the determined carrier densities $n$, dark conductivities $\sigma_{d}$, and photo responses $\sigma_{\mathrm{ph}} / \sigma_{d}$ of $\mu c-\mathrm{Si}: \mathrm{H}$ films with different oxygen concentrations. As one can see, all quantities are affected by the incorporation of oxygen in microcrystalline silicon. The carrier density and dark conductivity increase by nearly four orders of magnitude with increasing oxygen concentration from $1.1 \times 10^{19}$ to $1.9 \times 10^{21} \mathrm{~cm}^{-3}$. For the highest contamination level the doping efficiency of oxygen is in the order of $10^{-4}$. Photoresponse decreases with nearly two orders of magnitude for the same samples.

\section{F. Influence of nitrogen impurities on the solar cell performance}

To investigate the influence of nitrogen impurities on the performance of $\mu c-\mathrm{Si}: \mathrm{H}$ solar cells, a series of $\sim 1.2 \mu \mathrm{m}$ thick solar cells was prepared by inserting nitrogen and applying the same procedure as for oxygen impurities. During the $\mu c$-Si:H $i$-layer deposition process sharp nitrogen emission lines were observed in the optical emission spectra of the deposition plasma when applying the nitrogen leak. Figure 5(b) shows the recorded optical emission spectrum between 330 and $370 \mathrm{~nm}$ for a deposition with $\left(p_{\text {base }}=1.2\right.$ $\times 10^{-5}$ Torr) and without ( $p_{\text {base }}=4 \times 10^{-8}$ Torr) nitrogen leak. In this figure also the difference between the two spectra is plotted on a different scale so that three peaks at 337.1, 353.6 , and $358 \mathrm{~nm}$ are visible, which could be attributed to molecular bands of the second positive system of nitrogen. ${ }^{26}$
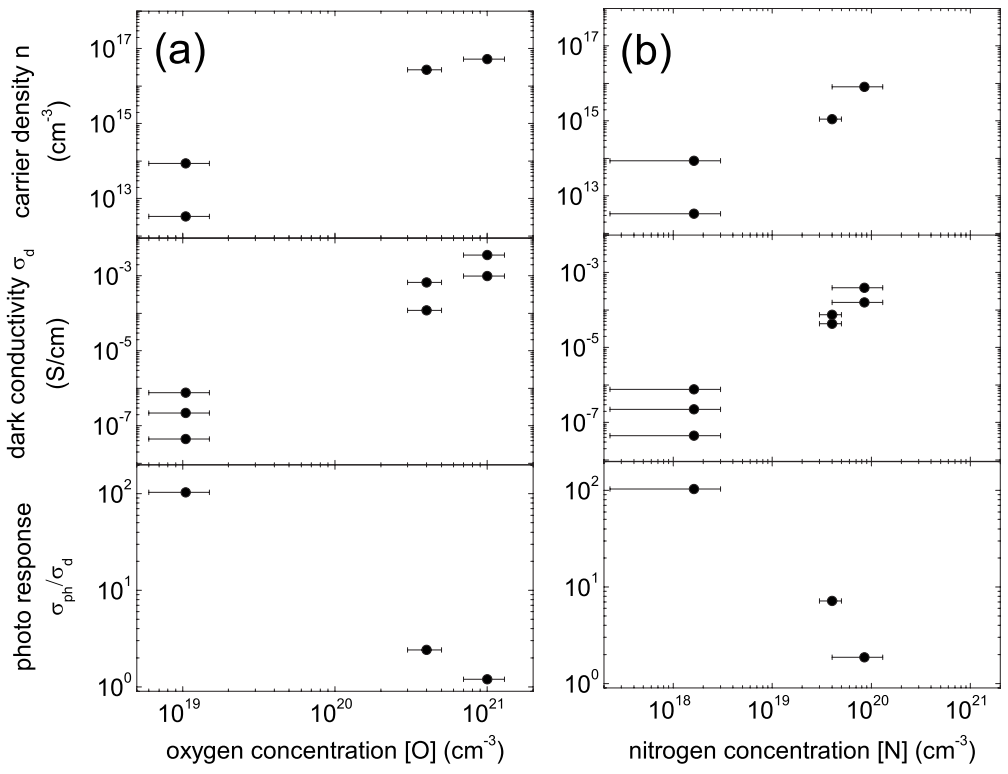

FIG. 10. Carrier density $n$, dark conductivity $\sigma_{d}$, and photoresponse $\sigma_{\mathrm{ph}} / \sigma_{d}$ of $\mu c$-Si:H films with different oxygen (a) and nitrogen (b) concentrations. 
In Fig. 5(c) the area of these three nitrogen peaks relative to the area of the continuum radiation was used as measure for the relative $\mathrm{N}_{2}{ }^{+}$emission. The signal was recorded as a function of the corresponding base pressure and obeys a 0.9 th power law. Thus, under the applied conditions the relative $\mathrm{N}_{2}{ }^{+}$emission can be used as a measure for the concentration of nitrogen in the deposition chamber and may be used as reactor-independent quantity to assess a nitrogen leak.

The correlation between adjusted base pressures and nitrogen concentrations in the $\mu c-\mathrm{Si}: \mathrm{H}$ absorber layers is also plotted in Fig. 5(c). At $i$-layer deposition conditions without intentional nitrogen leak, the base pressure in the $i$-chamber was $\sim 3 \times 10^{-8}$ Torr, and the measured nitrogen concentrations in the $i$-layers were in the range from $7 \times 10^{16}$ to 1.2 $\times 10^{18} \mathrm{~cm}^{-3}$. For a nitrogen leak size corresponding to a base pressure of $3 \times 10^{-7}$ Torr, the amount of incorporated nitrogen is only slightly higher than for $\mu c-\mathrm{Si}: \mathrm{H}$ depositions without nitrogen leak. However, with increasing nitrogen leak, the nitrogen concentration increases strongly and obeys a 1.3th power law with respect to the base pressure.

Figure 6(b) shows the $I-V$-parameters of $\mu c-\mathrm{Si}: \mathrm{H}$ solar cells as a function of the nitrogen content in the $\mu c-\mathrm{Si}: \mathrm{H}$ absorber layer. SIMS depth profiles revealed that for each of those solar cells, the oxygen content was sufficiently below the critical level $[\mathrm{O}]_{\text {critical }}\left([\mathrm{O}]<10^{19} \mathrm{~cm}^{-3}\right)$, so the following results can be interpreted as effects of nitrogen impurities alone. The silane concentration during $i$-layer deposition was adapted aiming to keep the open-circuit voltage values constant over the whole series. The $\mu c-\mathrm{Si}: \mathrm{H}$ solar cells with low nitrogen content were prepared at a silane flow of 3.3 SCCM, whereas the $\mu c-\mathrm{Si}: \mathrm{H}$ solar cell with the highest nitrogen content of $2.5 \times 10^{20} \mathrm{~cm}^{-3}$ was deposited at a silane flow of 3.0 SCCM. The figure shows that for nitrogen concentrations up to the range from $6 \times 10^{18}$ to $8 \times 10^{18} \mathrm{~cm}^{-3}$, the solar cell efficiency is not affected. Above this threshold similar effects can be observed as in the case of oxygen impurities. Due to a continuous reduction in short-circuit current density and fill factor, solar cell efficiency starts to drop with increasing nitrogen concentration. The shortcircuit current density and the fill factor under red light illumination decrease in parallel to the short-circuit current density and fill factor under AM1.5, while under blue light illumination short-circuit current density and fill factor remain almost the same or drop distinctly less strongly, respectively. Figure 7(b) shows the external QEs of $\mu c-\mathrm{Si}: \mathrm{H}$ solar cells with a nitrogen content of $4.4 \times 10^{17}$ and 1.3 $\times 10^{20} \mathrm{~cm}^{-3}$. The sample with high nitrogen concentration exhibits significant QE losses at wavelengths of $>500 \mathrm{~nm}$ compared to the reference $\mu c-\mathrm{Si}: \mathrm{H}$ solar cell. Also here, the external QE is enhanced under negative bias voltage conditions, indicating a charge collection problem in the cells.

\section{G. Correlation between nitrogen content and structural and electrical properties of $\mu c-\mathrm{Si}: \mathrm{H}$ films}

The influence of nitrogen impurities on structural and electrical properties of $\mu c-\mathrm{Si}: \mathrm{H}$ absorber layers was investigated. Raman spectra of solar cells with $i$-layers with different nitrogen contents were taken. They show that $\mu c-\mathrm{Si}: \mathrm{H}$ solar cells with high nitrogen content have similar crystalline volume fractions compared to solar cells with low nitrogen content and roughly equal open-circuit voltage [Fig. 8(b)]. Thereby it is demonstrated that the decrease in the shortcircuit current density is not explained by a reduction in the crystalline volume fraction for high nitrogen concentrations. The three samples with nitrogen concentrations of up to $7.5 \times 10^{19} \mathrm{~cm}^{-3}$ showed no shift in the crystalline peak toward lower wave numbers. Under the same deposition conditions, a series of separate $i$-layers with a thickness of 1.2 to $1.4 \mu \mathrm{m}$ has been deposited on glass and $c$-Si substrates. The Raman spectra were very similar compared to the cell results in Fig. 8(b). IR absorption spectra of these $\mu c-\mathrm{Si}: \mathrm{H}$ layers are shown in Fig. 9(b). It shows that the $2100 \mathrm{~cm}^{-1}$ mode is not present for the highest nitrogen impurity level that was prepared.

The performed Hall and conductivity measurements show that the electrical properties of $\mu c-\mathrm{Si}: \mathrm{H}$ films are sensitive to nitrogen impurities [Fig. 10(b)]. All samples were $n$-type. With increasing nitrogen content from $1.6 \times 10^{18}$ to $7.5 \times 10^{19} \mathrm{~cm}^{-3}$, the carrier density and dark conductivity increase nearly four orders of magnitude. The photoresponse decreases nearly two orders of magnitude.

\section{DISCUSSION}

The experiments are performed with an intentional impurity source (air, oxygen, or nitrogen leak) at the reactor wall, whereas the regular source gases are admitted directly into the plasma zone by means of a showerhead electrode. The experiments simulate contamination mechanisms originating from leaks or outgassing from the reactor walls during the $\mu c-\mathrm{Si}: \mathrm{H}$ deposition.

Both oxygen and nitrogen impurities in absorber layers were found to deteriorate the performance of $\mu c-\mathrm{Si}: \mathrm{H}$ solar cells if certain critical impurity levels are exceeded due to a significant decrease in fill factor and short-circuit current density. External QE measurements revealed that losses occur particularly in the wavelength range between 500 and $900 \mathrm{~nm}$, which is attributed to a deteriorated collection efficiency of charge carriers that are photogenerated in the $i$-layer bulk.

It is observed that a $\mu c-\mathrm{Si}: \mathrm{H}$ solar cell with the inhomogeneous oxygen and nitrogen impurity profile in Fig. 4(b) shows state-of-the-art $I-V$-values, although a large fraction of the $i$-layer volume has oxygen concentrations of up to $\sim 1$ $\times 10^{20} \mathrm{~cm}^{-3}$ and nitrogen concentrations of up to $\sim 2$ $\times 10^{20} \mathrm{~cm}^{-3}$, which are distinctly above the critical impurity levels in Figs. 6(a) and 6(b). Calculations of the average oxygen and nitrogen concentrations in the absorber layer in Fig. $4(\mathrm{~b})$ yield values of $[\mathrm{O}]_{\mathrm{av}}=4.2 \times 10^{19} \mathrm{~cm}^{-3}$ and $[\mathrm{N}]_{\mathrm{av}}$ $=8.4 \times 10^{19} \mathrm{~cm}^{-3}$. Microcrystalline solar cells with an evenly distributed oxygen contamination of $\sim 4$ $\times 10^{19} \mathrm{~cm}^{-3}$ lead to conversion efficiencies of $5.8 \%$ [Fig. $6(\mathrm{a})$. In the case of an evenly distributed nitrogen contamination of $\sim 8 \times 10^{19} \mathrm{~cm}^{-3}$, a cell efficiency of $5.0 \%$ was obtained [Fig. 6(b)]. Actually, these two values are significantly lower than the conversion efficiency of $7.4 \%$, which the $\mu c$-Si:H solar cell with the oxygen and nitrogen SIMS depth 
profile in Fig. 4(b) attains. Therefore, it can be concluded that the location of the contaminant atoms in the device plays a decisive role. If high concentrations are near to the $p / i$-interface, $\mu c$-Si:H solar cells react sensitively and the cell performance is strongly deteriorated. However, at high oxygen and nitrogen concentrations in the $i$-layer bulk or near to the $n / i$-interface, $\mu c-\mathrm{Si}: \mathrm{H}$ solar cells appear to react clearly less sensitively.

In the following we discuss which effect determines the $\mu c$-Si:H solar cell efficiency drop when the critical oxygen or nitrogen impurity levels are exceeded. The investigated different nitrogen concentrations exceeding the critical level in $\mu c$-Si:H films caused no increasing contribution from the $2100 \mathrm{~cm}^{-1}$ mode in the IR absorption spectra, whereas for $\mu c-\mathrm{Si}: \mathrm{H}$ films with oxygen impurities (in which series higher impurity concentrations were obtained), a prominent contribution of the $2100 \mathrm{~cm}^{-1}$ mode was obtained at the highest concentration. The contribution at $2000 \mathrm{~cm}^{-1}$ originates from $\mathrm{SiH}$ bonds in a compact environment, whereas the $2100 \mathrm{~cm}^{-1}$ mode is generally attributed to $\mathrm{SiH}$ bonds at void surfaces, ${ }^{27}$ indicating a more porous material structure. However the presence of oxygen atoms in the vicinity of $\mathrm{Si}-\mathrm{H}$ bonds can lead to a shift in the $2000 \mathrm{~cm}^{-1}$ mode toward $2100 \mathrm{~cm}^{-1}$ and of the $2100 \mathrm{~cm}^{-1}$ mode toward $2200 \mathrm{~cm}^{-1} .^{28}$ The presence of a contribution around $2200 \mathrm{~cm}^{-1}$ for the highest [O] in Fig. 9(a) is an indication that the shift should be at least partly attributed to the oxygen-induced increased vibration frequency of the $\mathrm{Si}-\mathrm{H}$ stretching modes as described in Ref. 28. Therefore, no unambiguous conclusion about the mechanism behind the higher $2100 \mathrm{~cm}^{-1}$ contribution for the highest oxygen concentration can be drawn at the present stage, i.e., there is no evidence for an increased oxygen-induced void concentration.

The solar cell results show that the short-circuit current density and the fill factor are deteriorated stronger if the contaminants are located close to the $p / i$-interface than if they are located close to the $n / i$-interface. Furthermore it is observed that the impurity induced decrease in the cell performance is stronger for $\mu c-\mathrm{Si}: \mathrm{H}$ solar cells with thick $i$-layers $(\sim 3 \mu \mathrm{m})$ compared to thin $i$-layers $(\sim 0.5 \mu \mathrm{m})$. These effects can be a result of a collection problem of charge carriers generated in the bulk of the $i$-layer. The external $\mathrm{QE}$ measurements of contaminated $\mu c-\mathrm{Si}: \mathrm{H}$ solar cells performed under negative dc bias show a significantly higher signal than without bias voltage. Also this indicates that the collection efficiency of the photogenerated charge carriers is reduced under influence of the impurities.

From the Hall measurements on $\mu c-\mathrm{Si}: \mathrm{H}$ layers it was deduced that microcrystalline silicon with oxygen or nitrogen impurities is $n$-type doped. From the literature it is known that for amorphous silicon the, defect density generally increases with increasing nitrogen or oxygen concentration. ${ }^{10-12}$ Based on the presented data, possible effects such as an increased defect density in the amorphous phase or a disturbance of the band diagram of the microcrystalline silicon based $p-i-n$ solar cell cannot be uniquely identified. It should be noted that for both investigated contaminant types at $i$-layer charge carrier densities of $10^{17} \mathrm{~cm}^{-3}$, the solar cell performance is heavily reduced, while at the low carrier concentration of $10^{15} \mathrm{~cm}^{-3}$, the cell performance is already affected.

\section{CONCLUSIONS}

Microcrystalline silicon layers prepared in an UHV system equipped with a gas purifier show impurity levels of roughly $[\mathrm{N}]=3 \times 10^{17} \mathrm{~cm}^{-1}$ and $[\mathrm{O}]=3 \times 10^{18} \mathrm{~cm}^{-1}$. An increase in these levels by means of intentional $\mathrm{N}_{2}$ and $\mathrm{O}_{2}$ leaks results in a decrease in the crystalline volume fraction. In order to compare the material properties at different impurity levels of materials with similar crystalline volume fractions, the source gas silane concentration during the deposition process was adjusted. The latter series shows an increase in the charge carrier density with increasing impurity level for oxygen and nitrogen, respectively. In both cases the $\mu c$-Si:H films were found to be $n$-type. The impurities also increase the charge carrier mobility in the material. Accordingly, the dark conductivity increases.

By preparing a series of $\mu c-\mathrm{Si}: \mathrm{H}$ solar cells with intentionally contaminated absorber layers, it was shown that both oxygen and nitrogen impurities deteriorate the cell performance when a specific critical level is exceeded. At $\sim 1.2 \mu \mathrm{m} i$-layer thickness, the determined levels are $[\mathrm{N}]_{\text {critical }}=6 \times 10^{18}-8 \times 10^{18} \mathrm{~cm}^{-3} \quad$ and $\quad[\mathrm{O}]_{\text {critical }}=1.2$ $\times 10^{19}-2 \times 10^{19} \mathrm{~cm}^{-3}$, respectively. The observed efficiency drop above the critical oxygen and nitrogen impurity levels is due to a decrease in fill factor and short-circuit current density. QE losses were particularly found in the wavelength range between 500 and $900 \mathrm{~nm}$.

It is found that $\mu c-\mathrm{Si}: \mathrm{H}$ based solar cells with thin $i$-layers are less sensitive to atmospheric contaminants compared to thick solar cells. The distribution of oxygen and nitrogen impurities within the $i$-layer affects the solar cell performance. A high impurity content near the $p / i$-interface is particularly critical, whereas a high impurity content in the $i$-layer bulk or near the $n / i$-interface barely deteriorates the solar cell performance. Additionally, air leak flows were found to deteriorate the $\mu c-\mathrm{Si}: \mathrm{H}$ solar cell performance if they exceed a fraction of 140-200 ppm related to the total gas flow during $i$-layer deposition.

\section{ACKNOWLEDGMENTS}

The authors thank W. Appenzeller, F. Birmans, G. Dingemans, M. Hülsbeck, U. Rau, S. Reynolds, V. Smirnov, H. Stiebig, C. Zahren, and B. Zwaygardt from the IEF5Photovoltaik for their contributions to this work.

\footnotetext{
${ }^{1}$ Y. Tawada, H. Yamagishi, and K. Yamamoto, Sol. Energy Mater. Sol. Cells 78, 647 (2003).

${ }^{2}$ T. Repmann, T. Kilper, W. Appenzeller, C. Zahren, H. Stiebig, and B. Rech, Proceedings of the 31st IEEE Photovoltaic Specialists Conference, Orlando, FL, 3-7 January 2005 (unpublished).

${ }^{3}$ P. Torres, J. Meier, R. Flückiger, U. Kroll, J. A. Anna Selvan, H. Keppner, A. Shah, S. D. Littelwood, I. E. Kelly, and P. Giannoulès, Appl. Phys. Lett. 69, 1373 (1996).

${ }^{4}$ U. Kroll, J. Meier, H. Keppner, and A. Shah, J. Vac. Sci. Technol. A 13, 2742 (1995).

${ }^{5}$ D. Hrunski, B. Rech, R. Schmitz, A. Mück, O. Pinçon, U. Breuer, and W. Beyer, Thin Solid Films 516, 4639 (2008).

${ }^{6}$ S. Vepřek, Z. Iqbal, R. O. Kühne, P. Capezzuto, F.-A. Sarott, and J. K.
} 
Gimzewski, J. Phys. C 16, 6241 (1983).

${ }^{7}$ R. Flückiger, J. Meier, M. Goetz, and A. Shah, J. Appl. Phys. 77, 712 (1995).

${ }^{8}$ T. Kamei and T. Wada, J. Appl. Phys. 96, 2087 (2004).

${ }^{9}$ T. Ehara, Appl. Surf. Sci. 113-114, 126 (1997).

${ }^{10}$ T. Kamei, M. Kondo, and A. Matsuda, Jpn. J. Appl. Phys., Part 2 37, L265 (1998).

${ }^{11}$ F. Finger, J. Müller, C. Malten, R. Carius, and H. Wagner, J. Non-Cryst. Solids 266-269, 511 (2000).

${ }^{12}$ M. Vaněček, A. Poruba, Z. Remeš, J. Rosa, S. Kamba, V. Vorliček, J. Meier, and A. Shah, J. Non-Cryst. Solids 266-269, 519 (2000).

${ }^{13}$ L. L. Kazmerski and J. R. Dick, J. Vac. Sci. Technol. A 2, 1120 (1984).

${ }^{14}$ Y. Nasuno, M. Kondo, and A. Matsuda, Sol. Energy Mater. Sol. Cells 74 497 (2002).

${ }^{15}$ J. Woerdenweber, T. Merdzhanova, R. Schmitz, A. Mück, U. Zastrow, L. Niessen, A. Gordijn, R. Carius, W. Beyer, H. Stiebig, and U. Rau, J. Appl. Phys. 104, 094507 (2008).

${ }^{16}$ O. Kluth, G. Schöpe, J. Hüpkes, C. Agashe, J. Müller, and B. Rech, Thin Solid Films 442, 80 (2003).

${ }^{17}$ B. Rech, T. Roschek, J. Müller, S. Wieder, and H. Wagner, Sol. Energy Mater. Sol. Cells 66, 267 (2001).
${ }^{18}$ A. Mück, U. Zastrow, O. Vetterl, and B. Rech, in Secondary Ion Mass Spectrometry - SIMS XII, edited by A. Benninghofen, P. Bertrand, H.-N. Migeon, and H. W. Werner, (Elsevier, Amsterdam, 2000), p. 698.

${ }^{19}$ L. Houben, M. Luysberg, P. Hapke, R. Carius, and H. Wagner, Philos. Mag. A 77, 1447 (1998).

${ }^{20}$ M. Luysberg, C. Scholten, L. Houben, R. Carius, F. Finger, and O. Vetterl, Mater. Res. Soc. Symp. Proc. 164, 39 (2001).

${ }^{21}$ T. Bronger and R. Carius, Thin Solid Films 515, 7486 (2007).

${ }^{22}$ O. Vetterl, F. Finger, R. Carius, P. Hapke, L. Houben, O. Kluth, A. Lambertz, A. Mück, B. Rech, and H. Wagner, Sol. Energy Mater. Sol. Cells 62, 97 (2000).

${ }^{23}$ T. Roschek, T. Repmann, J. Müller, B. Rech, and H. Wagner, J. Vac. Sci. Technol. A 20, 492 (2002).

${ }^{24}$ Th. Englert, G. Abstreiter, and J. Pontcharra, Solid-State Electron. 23, 31 (1980).

${ }^{25}$ S. Piscanec, M. Cantoro, A. C. Ferrari, J. A. Zapien, Y. Lifshitz, S. T. Lee, S. Hofmann, and J. Robertson, Phys. Rev. B 68, 241312 (2003).

${ }^{26}$ R. W. B. Pearse and A. G. Gaydon, The Identification of Molecular Spectra (Chapman and Hall, London, 1984).

${ }^{27}$ H. Wagner and W. Beyer, Solid State Commun. 48, 585 (1983).

${ }^{28}$ G. Lucovsky and W. B. Pollard, Physica B \& C 117-118, 865 (1983). 